\title{
Immunogenic DNA-related Factors

\author{
Nucleosomes Spontaneously Released from Normal Murine Lymphoid Cells Stimulate \\ Proliferation and Immunoglobulin Synthesis of Normal Mouse Lymphocytes
}

David A. Bell, Brian Morrison, and Patricia VandenBygaart

Departments of Medicine and Microbiology \& Immunology, University of Western Ontario

and University Hospital, London, Ontario, Canada N6A 5 A5

\begin{abstract}
The cell-free supernatants of normal spleen and thymus lymphocytes in short-term culture release low molecular weight (LMW) DNA protein molecules that have an immunoproliferative effect (polyclonal $B$ cell activation) in vitro. We have determined that the protein-LMW DNA complexes responsible for these effects are nucleosomal constituents of chromatin, since the mitogenically active fractions of these cell-free supernatants contain the constituents of core histones $(\mathrm{H3}, \mathrm{H} 2 \mathrm{~A}$, H2B, H4) together with LMW DNA (140-180 bp), and since the immunoproliferative effects of these cell-free supernatants could be mimicked by various other nucleoprotein preparations (including calf thymus and chicken erythrocyte nucleosomes). The spontaneous cellular release of cleaved chromatin constituents in vitro can be attributed to a form of programmed cell death termed apoptosis, since the cultured spleen cells exhibited (a) morphologic evidence consistent with this process by electron microscopy, and (b) evidence of intracellular cleavage of chromatin which, like apoptosis, could be blocked with $\mathrm{ZnSO}_{4}$. This resulted in inhibition of the extracellular release of nucleosomal constituents as well as the immunoproliferative effects of the cell-free supernatants. The immunoproliferative effect of nucleosomes released from cells during apoptosis could be responsible for previously observed spontaneous in vitro anti-DNA and anti-histone antibody responses of murine spleen cells, and in vivo in normal lymphoid tissues, resulting in renewed cellular proliferation after cell death. In pathological states, this could result in abnormal polyclonal B cell proliferation and autoantibody formation. (J. Clin. Invest. 1990. 85:1487-1496.) apoptosis • immunoproliferation • nucleosomes • autoimmunity • DNA
\end{abstract}

\section{Introduction}

Although it is well established that anti-DNA autoantibodies play an important role in the development of systemic lupus erythematosis (SLE), ${ }^{1}$ the factors responsible for the induction

Address correspondence to Dr. David A. Bell, University Hospital RDU, Box 5339, London, Ontario, Canada N6A 5A5.

Received for publication 9 November 1988 and in revised form 20 December 1989.

1. Abbreviations used in this paper: HMW, high molecular weight; LMW, low molecular weight; PFC, plaque-forming cells; SLE, systemic lupus erythematosus; $\mathrm{SNH}$, soluble nucleohistones; sPBA, soluble polyclonal B cell activator.

J. Clin. Invest.

(c) The American Society for Clinical Investigation, Inc. $0021-9738 / 90 / 05 / 1487 / 10 \quad \$ 2.00$

Volume 85, May 1990, 1487-1496 of this antibody response are still not clearly established. However, a number of different studies have revealed that the potential to produce anti-DNA antibodies exists in normal individuals (1-3), and through the analysis of common anti-DNA idiotypes in normals and $\operatorname{SLE}(4,5)$ it may be concluded that Ig genes often of germline origin (6) encoding this response in SLE are shared with normal individuals. It is not yet clear, however, whether the expansion of B cells with this potential, leading to the expression of anti-DNA antibodies in SLE patients, occurs under the influence of antigen or immunogenic epitopes that crossreact with DNA, or nonspecifically by endogenous polyclonal $\mathrm{B}$ cell activators.

As an approach to assessing some of these problems, we have studied the factors responsible for the induction and regulation of an in vitro anti-DNA antibody response shared with normal or autoimmune spleen cells of mice $(1,7,8)$. We have noted in these studies that the cell-free supernatants of these cultured murine lymphoid cells contain DNA-related immunogenic factors which might play a role in the induction of anti-DNA antibody responses (7). A low molecular weight (LMW) protein-free DNA molecule extracted from these culture supernatants, when injected into mice or added to cultures of murine spleen cells, specifically induced or augmented anti-DNA antibody responses, but had no effect on other unrelated antibody responses (8). This remarkable immunogenic property of LMW DNA distinguished it from DNA molecules of larger size ( $>300 \mathrm{bp}$ ) known to be nonimmunogenic. The LMW DNA appeared to act by stimulating $T_{H}$ cells, although the basis for this effect has not been determined. A second LMW DNA-related immunogenic factor, soluble polyclonal B cell activator (sPBA), with somewhat different properties was also identified in the cell-free supernatants of cultured spleen cells of both normal and autoimmune mice (9). This DNA protein-containing factor, which lacked properties of IL-1 or IL-2, could also augment anti-DNA antibody responses, but its effects could only be abrogated with DNase plus protease, and its ability to augment anti-DNA antibody responses appeared to result from its direct mitogenic influence on B cells, resulting in a polyclonal antibody response in vitro. On the basis of these different effects produced by these DNA-related molecules, we considered that the mitogenic effect of the second factor (sPBA) depended on the existence of its associated protein moiety, which conferred on the LMW DNA associated with it a more general immunoproliferative effect.

Since sPBA contained both LMW DNA $(<160-180 \mathrm{bp})$ and a protein moiety, we considered that this second factor represented the core nucleosomes of chromatin released spontaneously in the culture supernatant. The LMW DNA in core nucleosomes has a molecular weight similar to that present in the factor, and surrounds a histone octomer that could protect the DNA from direct nuclease digestion in vitro (10). The 
present studies, which confirm this hypothesis and reveal that the constituents of these immunogenic supernatants contain core histones in association with LMW DNA, also show that purified core nucleosomes isolated from different sources share the immunogenic properties of SPBA. In addition, the present studies provide evidence that constituents of core nucleosomes are released from cultured murine lymphoid cells spontaneously in a manner similar to a form of programmed cell death termed apoptosis (11), previously shown to occur morphologically in normal tissues in vivo (12). The inhibition of this process by the addition of $\mathrm{ZnSO}_{4}$ blocked the cellular release of the DNA and histone constituents of sPBA into the cell-free supernatant and resulted in the complete abrogation of the immunoproliferative effects of these supernatants.

\section{Methods}

Mice

NZW, NZB, DBA/2J, and C57Bl6/J mice were obtained from Jackson Laboratory, Bar Harbor, ME. DBA/2J, C57B16/J, and B/W hybrid mice were bred from these parent strains in our laboratory.

\section{Antigens and mitogens}

Sheep erythrocytes suspended in Alsever's solution were obtained from Woodlyn Laboratories, Guelph, Ontario, Canada. For coupling to protein A for the detection of Ig plaque-forming cells (PFC) (13), sheep red blood cells (SRBC) were washed three times in saline. To one packed cell volume of $S R B C$, an equal volume $(0.5 \mathrm{mg} / \mathrm{ml})$ of protein A (Pharmacia Canada Inc., Dorval, Quebec, Canada) in $0.85 \% \mathrm{NaCl}$ and an equal volume of fresh $(0.75 \mathrm{mg} / \mathrm{ml})$ chromium chloride $(\mathrm{J}$. T. Baker Chemical Co., Phillipsburg, NJ) in saline were added, mixed by hand for $10 \mathrm{~min}$, and then incubated at $37^{\circ} \mathrm{C}$ for $15 \mathrm{~min}$. The coupled cells were washed in Dulbecco's PBS (Gibco Laboratories, Grand Island, NY) before use.

PWM (Gibco Laboratories) was diluted in MEM to develop concentrations for optimal stimulation of human lymphoid cells.

SPBA isolation has been described previously (9). Briefly, single cell suspensions of mouse spleen cells or thymocytes in HBSS (Gibco Laboratories) were cultured at $1.5 \times 10^{6}$ lymphoid cells $/ \mathrm{ml}$ of serum-free Eagle's MEM (Gibco Laboratories) with $10 \mathrm{mM}$ Hepes, pH 7, $2 \mathrm{mM}$ glutamine, $1 \mathrm{mM}$ sodium pyruvate, and $0.1 \mu \mathrm{g} / \mathrm{ml}$ gentamycin. 3 or 4 $\mathrm{d}$ after culture initiation cells were pelleted by centrifugation, and the cell-free supernatant was passed through a $0.45-\mu \mathrm{m}$ membrane (Nalge Co., Rochester, NY). These filtered supernatants were dialyzed with a 100 -fold volume of $0.85 \%$ saline through a PM 30 ultrafiltration filter (Amicon Corp., Danvers, MA) or a PTTK Minitan plate (Millipore/ Continental Water Systems, Bedford, MA) and concentrated fourfold. The supernatants $(>30 \mathrm{kD})$ were either used immediately, or frozen at $-20^{\circ} \mathrm{C}$ for long-term storage or at $4^{\circ} \mathrm{C}$ for briefer periods of time.

Nucleohistone preparations (soluble nucleohistones [SNH]) were obtained from Sigma Chemical Co. (St. Louis, MO), and with constant stirring were dissolved slowly up to $1 \mathrm{wk}$ in PBS or $5 \mathrm{mM} 0.85 \%$ saline. Any insoluble material from the PBS- or $0.85 \%$ saline-dissolved SNH was removed by centrifugation at $2,000 \mathrm{~g}$ for $10 \mathrm{~min}$.

Calf thymus nucleosomes were the kind gift of Dr. Stephen Karlic, University of Western Ontario, and were prepared as follows: Calf thymus tissue was homogenized in $85 \mathrm{mM} \mathrm{NaCl}, 50 \mathrm{mM} \mathrm{NaHSO}_{3}$, and $3 \mathrm{mM} \mathrm{MgCl}$, $\mathrm{pH}$ 7.5. After filtration through cheesecloth, the nuclei were successively washed with bisulphite solution, leaving a chromatin pellet that was then dialyzed against $10 \mathrm{mM}$ Tris and $1 \mathrm{mM}$ EDTA, pH 8.0 (Tris-EDTA, or TE), and then washed with $10 \mathrm{mM}$ Tris buffer, pH 8.0. The chromatin pellet was digested by micrococcal nuclease in the presence of $\mathrm{CaCl}_{2}$ and the chromatin was solubilized by washing the pellet with TE. Nucleosomes in TE were then separated on a Bio Gel A-15 gel (Bio-Rad Chemical Division, Mississauga, Ontario, Canada) into different multimers. The multimer sizing was evaluated on agarose gels. The monomers of chromatin were then dialyzed three times against a 1,000 -fold volume of $5 \mathrm{mM} \mathrm{NaCl}$ (14).
Chicken erythrocyte core mononucleosomes were the gift of Dr. Peter N. Lewis, Department of Biochemistry, University of Toronto, and were prepared as follows: The nucleosomes were isolated by solubilizing chromatin from purified chicken erythrocyte cell nuclei with micrococcal nuclease (15). The solubilized chromatin was then stripped of $\mathrm{H} 1$ and $\mathrm{H} 5$ histones and nonhistone proteins by gel filtration on Bio Gel P100 in $10 \mathrm{mM}$ Tris- $\mathrm{HCl}$ and $0.65 \mathrm{M} \mathrm{NaCl}$. The H1/H5-stripped chromatin was then redigested with micrococcal nuclease and mononucleosomes were isolated by gel filtration on Sephacryl S-300 eluted with $10 \mathrm{mM}$ Tris-cacodylate and $0.7 \mathrm{mM}$ EDTA, pH 7.4. Cacodylate was toxic and could be removed by extensive dialysis (1,000-fold dialysis four times vs. $5 \mathrm{mM}$ saline) or by precipitating the nucleosomes from Tris-cacodylate buffer with $15 \mathrm{mM} \mathrm{MgCl}_{2}$. However, only the $\mathrm{MgCl}_{2}$ precipitation yielded sPBA-like activity. Naked DNA was prepared from these preparations as previously described (8).

The DNA concentration of each preparation used was estimated using a modification of the diphenylamine method (16). Calf thymus DNA at various concentrations up to $100 \mu \mathrm{g} / \mathrm{ml}$ was used to develop a standard curve for this assay.

\section{SDS gel electrophoresis}

The Laemmli SDS polyacryalmide gel system modified for improved resolution of histones by Thomas and Kornberg (17) was used in a Protean II apparatus (Bio-Rad Laboratories, Richmond, CA). The stacking gel was $4 \%$ acrylamide (Bio-Rad Laboratories) and $0.2 \%$ bisacrylamide (Bio-Rad Laboratories). The resolving gel was $18 \%$ acrylamide and $0.09 \%$ bis-acrylamide.

Protein molecular weight markers consisting of insulin $(3,000 \mathrm{~mol}$ $w t)$, bovine trypsin inhibitor $(14,300 \mathrm{~mol} \mathrm{wt}), \gamma$-lactoglobulin $(18,400$ $\mathrm{mol} \mathrm{wt}), \alpha$-chymotrypsin $(25,700 \mathrm{~mol} \mathrm{wt})$, and ovalbumin $(43,000 \mathrm{~mol}$ wt) were obtained from Bethesda Research Laboratories, Gaithersburg, MD. The chicken erythrocyte core histone marker was prepared by Dr. P. N. Lewis (15) as described previously. Individual calf thymus histone preparations of $\mathrm{H} 1, \mathrm{H} 3$ with some $\mathrm{H} 2 \mathrm{~A}$, and $\mathrm{H} 4$ were processed by Dr. Jit Gohill, University of Calgary, as previously described (18). sPBA and SNH histones were isolated as previously described (19). The gels were run at $20 \mathrm{~mA}$ for $6 \mathrm{~h}$ at a constant current and stained in brilliant blue R250 (Sigma Chemical Co.) (19).

\section{Isolation of nuclei and DNA fragments}

Nuclei from mouse spleen cells were prepared by the method of Miovic and Pizer (20) as modified by Duke et al. (21). Pelleted washed mouse spleen cells were resuspended at $4^{\circ} \mathrm{C}$ in $10 \mathrm{mM}$ Tris- $\mathrm{HCl}$, pH 7.5, 145 $\mathrm{mM} \mathrm{NaCl}$, and $5 \mathrm{mM} \mathrm{MgCl}_{2}$ at $5 \times 10^{6}$ cells in $1 \mathrm{ml}$. Triton $\mathrm{X}-100$ was added to $0.2 \%$ cells. The cells were disrupted in a Dounce homogenizer (Kontes Glass Co., Vineland, NJ) on ice. This mixture was then layered on $1 \mathrm{ml}$ cold $25 \%$ glycerol containing $5 \mathrm{mM} \mathrm{MgCl}$ and buffered by $10 \mathrm{mM}$ Tris- $\mathrm{HCl}$, pH 7.5. The nuclei were sedimented at $200 \mathrm{~g}$ for $10 \mathrm{~min}$ at $4^{\circ} \mathrm{C}$. The nuclear pellet was then resuspended in $1 \mathrm{ml}$ of $10 \mathrm{mM}$ Tris- $\mathrm{HCl}, \mathrm{pH} 7.5,145 \mathrm{mM} \mathrm{NaCl}, 1 \mu \mathrm{g} / \mathrm{ml}$ protease $\mathrm{K}(\mathrm{Be}-$ thesda Research Laboratories) and $0.1 \%$ SDS and incubated at $65^{\circ} \mathrm{C}$ for $1 \mathrm{~h}$. The DNA was then extracted twice with an equal volume of phenol and then with chloroform with a 1:25 volume of isoamyl alcohol. The DNA was then precipitated overnight in $70 \%$ ethanol. Samples representing $1.5 \times 10^{6}$ cells were run on $2 \%$ agarose gel in $0.089 \mathrm{M}$ Tris, $0.089 \mathrm{M}$ boric acid, and $0.002 \mathrm{M}$ EDTA, pH 8.0 (22). The supernatant was sterile filtered for the isolation of supernatant LMW DNA after the cells had been pelleted. SDS and protease $\mathrm{K}$ was added to $0.5 \mathrm{ml}$ of supernatant to $0.1 \%$ and $1 \mu \mathrm{g} / \mathrm{ml}$, respectively. The supernatant was then incubated at $65^{\circ} \mathrm{C}$ for $1 \mathrm{~h}$ and the DNA extracted as described for nuclear DNA. Each lane represented the supernatant from $1.5 \times 10^{6}$ cells $/ \mathrm{ml}$.

\section{Cell cultures}

Mouse lymphoid cells. Mouse spleen cells were homogenized in a Dounce homogenizer to a single cell suspension in HBSS, washed once in HBSS, and resuspended to $10 \times 10^{6} / \mathrm{ml}$ viable cells in the described media. These mouse lymphoid cells were then incubated for 4-5 $\mathrm{d}$ in a 
Mishell-Dutton system with $10 \% \mathrm{CO}_{2}$ in room air at $37^{\circ} \mathrm{C}$ (9). After culture the cells were pelleted, washed once with HBSS, and resuspended at $2-4 \times 10^{5}$ viable cells $/ \mathrm{ml}$ in HBSS, prepared for the antibody assay (see below).

Mitogenic responses of mouse spleen cells were assayed as described previously (9), except that serum-free RPMI was used since it permitted a superior response. $5 \times 10^{5}$ mouse spleen cells $/ \mathrm{ml}$ were cultured in a $10 \% \mathrm{CO}_{2}$ chamber and pulsed at $24 \mathrm{~h}$ with $0.2 \mu \mathrm{Ci} /$ well of $\left[{ }^{3} \mathrm{H}\right]$ thymidine (Amersham Co., Oakville, Ontario, Canada) and harvested $24 \mathrm{~h}$ later by a Skatron cell harvester (Flow Laboratories, Mississauga, Ontario, Canada).

Antibody assay of cultured lymphoid cells. Ig synthesis of murine lymphoid cells in culture was quantitated using a hemolytic PFC assay in which Staphylococcal aureus protein A (protein A) was coupled to indicator SRBC to measure total Ig PFC (13). $100 \mu \mathrm{l}$ of $2-4 \times 10^{5}$ viable cells were mixed with $50 \mu \mathrm{l}$ of $10 \%$ protein A-coupled SRBC in HBSS and $400 \mu \mathrm{l}$ of heated $\left(40^{\circ} \mathrm{C}\right) 0.4 \%$ agarose (sea plaque; FMC Corporation, Rockland, ME) on a microscope slide. The plaques were developed at $37^{\circ} \mathrm{C}$ in a humid atmosphere in the presence of a $1: 50$ dilution of goat anti-mouse Ig (DAKOPATTS, Copenhagen, Denmark) for $90 \mathrm{~min}$, followed by a 45 -min incubation with $5 \%$ hemlo guinea pig complement (Cedarlane, Toronto, Ontario, Canada). The number of plaques was enumerated directly, using a magnifying glass. Controls consisting of SRBC without protein A, or protein A-coupled SRBC without lymphoid cells were $<1 \%$ of the background responses.

Inhibition of apoptosis with $\mathrm{ZnSO}_{4}$. A single cell suspension of mouse spleen or thymus cells was prepared as previously described for mitogen, plaquing, and sPBA isolation. $10 \times 10^{6}$ viable cells $/ \mathrm{ml}$ in 15-ml 25100-25 flasks (Corning Glass Works, Corning, NY) were incubated for $2 \mathrm{~h}$ in MEM with $0.01 \mathrm{mCi} / \mathrm{ml}$ of $\left[{ }^{3} \mathrm{H}\right]$ thymidine (Amersham Corp.). Cells were cultured in $10 \% \mathrm{CO}_{2}$ at $37^{\circ} \mathrm{C}$ on a rocking platform. Cells were pelleted, washed once with HBSS, and resuspended at $1.5 \times 10^{6}$ cells $/ \mathrm{ml}$ in MEM with $10 \% \mathrm{FCS}$ and the required amount of $\mathrm{ZnSO}_{4}$. Triplicate cultures were incubated, and at different time periods of incubations $1-\mathrm{ml}$ samples were removed from each culture for testing. In triplicate, the cells were pelleted and washed once with HBSS. In the first set of experiments the supernatants were filtered through a $0.22-\mu \mathrm{m}$ syringe filter and $0.5 \mathrm{ml}$ was precipitated with ice-cold 12.5\% TCA onto GF/A filters (Whatman Laboratory Products Inc., Clifton, NJ), washed twice with $10 \%$ TCA, and washed twice more with cold $70 \%$ ethanol. After drying, the counts per minute of $\left[{ }^{3} \mathrm{H}\right]$ thymidine were determined. The mean and standard deviation of counts per minute of $\left[{ }^{3} \mathrm{H}\right]$ thymidine for the three supernatants was then calculated. The relative proportion of high molecular weight (HMW) and LMW intracellular DNA was determined after first lysing the cells to obtain intracellular DNA. The labeled DNA that was pelleted at $27,000 \mathrm{~g}$ for $30 \mathrm{~min}$ was considered to be HMW DNA, while the DNA left in the supernatant after this centrifugation was considered to be LMW DNA. The HMW DNA was considered to represent uncleaved chromatin and the LMW DNA was considered to represent cleaved chromatin. The HMW chromatin fraction was resuspended in $10 \mathrm{mM}$ Tris and $1 \mathrm{mM}$ EDTA, pH 8. Both sets of samples in triplicate for each time point were then TCA precipitated and prepared as described with SPBA onto GF/A filters. The mean and standard deviation of counts per minute of $\left[{ }^{3} \mathrm{H}\right]$ thymidine of each set were then calculated (standard deviations were $10 \%$ of the mean or less) and the relative proportion of HMW DNA (pelleted chromatin) vs. LMW (nonpelleted chromatin) was determined. The following is an example of how the percentage of supernatant LMW DNA and the intracellular HMW and LMW DNA were calculated:

$\%$ supernatant (S/N) LMW DNA

$$
\text { mean cpm S/N LMW uncleaved chromatin }
$$

mean cpm S/N LMW cleaved chromatin + mean cpm HMW
uncleaved chromatin + mean cpm intracellular LMW chromatin

In some experiments cells were incubated with $\mathrm{ZnSO}_{4}$ to attempt to block the release of sPBA. In these experiments normal mouse spleen cells were cultured as described before for the preparation of sPBA with a few crucial changes. The cells were grown in MEM with 10\% FCS, 2
mM glutamine, $1 \mathrm{mM}$ sodium pyruvate, $0.1 \mathrm{mM}$ nonessential amino acids, $0.1 \mu \mathrm{g} / \mathrm{ml}$ gentamycin, and a given concentration of $\mathrm{ZnSO}_{4}(0$, $0.01,0.1,0.25,0.5$, and $1.0 \mathrm{mM} \mathrm{ZnSO}_{4}$ ). Control cultures contained medium with no $\mathrm{ZnSO}_{4}$ and no cells. The $>30-\mathrm{kD}$ sPBAs were then dialyzed vs. $0.9 \%$ saline (1,000:1, changed four times). These samples were then used as a source of sPBA in the mitogen assay described previously.

Morphologic assessment of cultured mouse spleen and thymocytes for evidence of apoptosis. Mononuclear cells from normal DBA/2 mouse spleen and thymus were prepared as described for cell cultures. Noncultured cells were left in medium for $2 \mathrm{~h}$ only, and cultured cells were suspended in the same medium for 24,48 , or $72 \mathrm{~h}$. The noncultured cells were left in the refrigerator overnight in fixative. Cells were fixed for $\sim 1 \mathrm{~h}$ in $1.5 \%$ gluteraldehyde made up in $0.1 \mathrm{M}$ phosphate buffer. They were washed three times in $0.1 \mathrm{M}$ phosphate buffer, postfixed for $1 \mathrm{~h}$ at room temperature in buffered $1 \% \mathrm{OsO}_{4}$, washed twice with distilled water, dehydrated using graded ethanol series, infiltrated with Spurr resin, and polymerized at $60^{\circ} \mathrm{C}$ overnight.

Blocks were sectioned and sections were stained with $1 \%$ aqueous uranyl acetate and Reynolds lead citrate.

Statistical analysis. Statistical analysis used the paired $t$ test to determine significant differences in paired samples.

\section{Results}

\section{Nucleohistones mimic the mitogenic effects of $S P B A$}

In a previous report it was observed that the mitogenic effects of SPBA were abrogated by combined DNase and protease (or trypsin) digestion together, suggesting that its effect was dependent on a DNA/protein moiety. Since the LMW DNA present in SPBA is similar to the LMW DNA of core mononucleosomes, it was reasoned that SPBA might represent nucleosomes. Experiments were therefore undertaken to determine if the mitogenic effects of SPBA could be mimicked by isolated purified nucleohistone preparations. The mitogenic effect of SPBA was compared with nucleohisstones from a variety of sources, including a commercial preparation of SNH (Sigma Chemical Co.) and nucleosomes isolated from both calf thymus and chicken erythrocytes. Fig. 1 compares the mitogenic effect of SPBA and SNH on normal mouse splenocytes in vitro, and at different equivalent DNA concentrations. Both SNH and sPBA (OD 260/280 = 1.5) had similar mitogenic effects at relatively low equivalent concentrations of DNA (0.1 $\mu \mathrm{g}$ ), while naked DNA (OD 260/280 = 1.8) (22), extracted from each of the above preparations and used at up to 30 times higher equivalent concentrations of DNA, had virtually no mitogenic influence on these cells. This lack of mitogenicity of naked DNA at these concentrations was not due to trivial effects in the assay system such as competition of naked DNA for $\left[{ }^{3} \mathrm{H}\right]$ thymidine, since this DNA caused no suppression of background responses of $\left[{ }^{3} \mathrm{H}\right]$ thymidine, nor did it have suppressive effects on other mitogens such as PWM (data not shown). Furthermore, in some preparations very high concentrations of naked DNA ( $>50-100 \mu \mathrm{g}$ ) occasionally showed a weak mitogenic effect on murine spleen cells.

These experiments, therefore, indicate that the mitogenic effect of sPBA could be mimicked by these nucleohistone preparations, and that the mitogenic effects of these preparations were dependent on the presence of an associated protein (histone) moiety. Isolated nucleosome preparations were also mitogenic for spleen cells, and the dose-response curves paralleled those obtained with sPBA. Fig. 2 is a representative experiment that shows a comparison of the mitogenic effect of sPBA and chicken erythrocyte nucleosomes at various DNA 


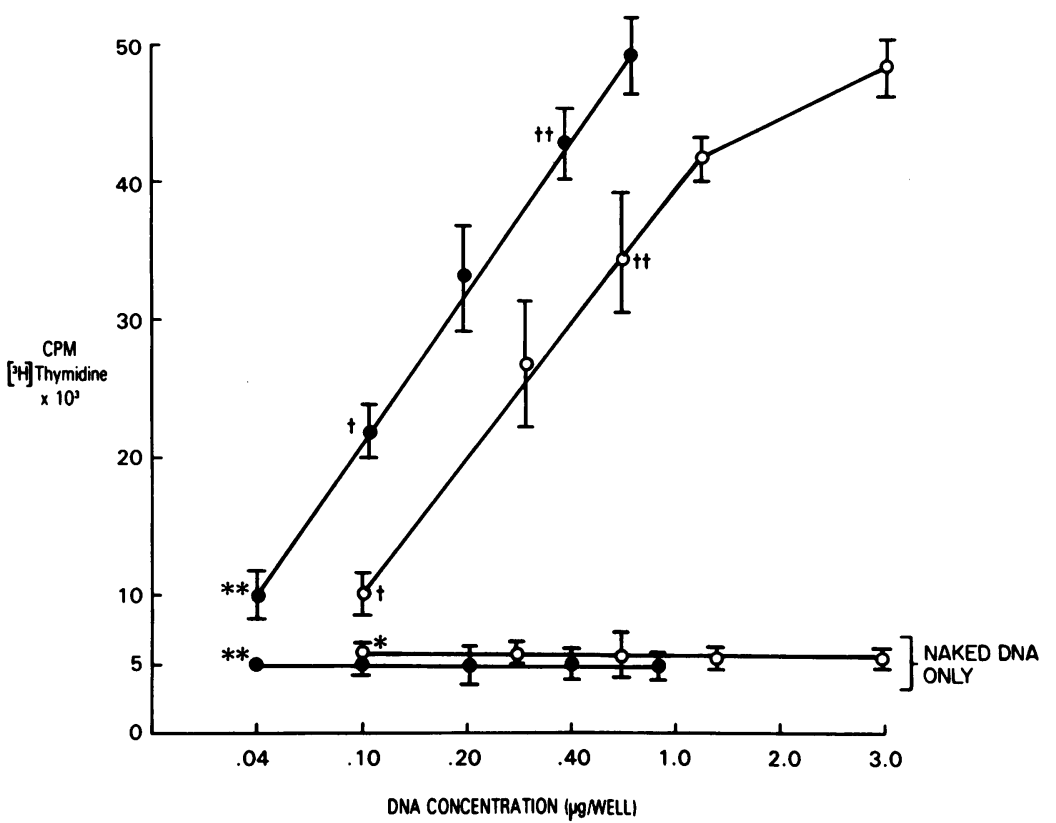

Figure 1. Comparison of the proliferative response of normal (DBA/2) mouse spleen cells to sPBA or nucleohistones (SNH). The proliferative response of normal (DBA) spleen cells $\left(5 \times 10^{5}\right)$ cultured in quadruplicate is shown in serum-free RPMI in the presence of increasing quantities, in DNA equivalents, of SPBA (๑) or SNH (O) which was either untreated or phenol chloroform-extracted and protein-free (naked DNA). Cultures were pulsed at $24 \mathrm{~h}$ with $\left[{ }^{3} \mathrm{H}\right]$ thymidine and harvested at 48 h. $P<0.005\left(^{* *}\right.$ vs. ${ }^{* *} ; \dagger$ vs. $\dagger ; \dagger$ vs. ${ }^{*}$; and $\dagger \dagger$ vs. $\left.\dagger \dagger\right)$. concentrations in each preparation used. In all experiments isolated nucleosomes and SPBA showed a consistent mitogenic effect at relatively low DNA concentrations. As expected, in some experiments using different sources of spleen cells in culture both for the preparation of sPBA and for the response to this material, some variations in the dose-response curves were seen (compare sPBA response in Fig. 1 vs. Fig. 2). In general, the response to isolated nucleosome preparations of calf thymus (data not shown) or chicken erythrocyte nucleosomes (Fig. 2) was somewhat higher than sPBA. In contrast to the mitogenic effect seen with sPBA and nucleosomes, isolated DNA-free histones, like naked DNA, had no mitogenic effect on mouse spleen cells (data not shown).

\section{SPBA contains constituents of core nucleosomes}

The foregoing experiments indicating that the mitogenic effect of SPBA could be mimicked by various nucleohistone preparations implied that SPBA contained the constituents of core nucleosomes. Direct analysis of sPBA was next undertaken to determine if this material also contained core histones. In these experiments, mitogenically active fractions of sPBA, nucleohistone from SNH, calf thymus, and chicken erythrocyte nucleosomes were analyzed on SDS gels for the presence of histones characteristic of core nucleosomes. Fig. 3 shows an SDS-PAGE containing purified histone standards of $\mathrm{H} 4, \mathrm{H} 3$ and $\mathrm{H} 2 \mathrm{~A}$, and $\mathrm{H} 1$ (lanes $1-3$ ); chicken erythrocyte nucleosomes (lane 4); calf thymus nucleosomes (lane 5); sPBA (lane 6 ); and two different concentrations (20 and $40 \mu \mathrm{g}$, respectively) of SNH (lanes 7 and 8). Molecular weight markers are shown in lane 9. This representative gel shows that the $M_{\mathrm{r}}$ pattern of the sPBA was indistinguishable from that seen with purified histone preparations from core nucleosomes and is similar to the mitogenically active nucleohistone fractions obtained from other sources. A comparison of different gels revealed that $\mathrm{H} 1$ was not consistently present in all mouse SPBA preparations (compare with Fig. 3, lane 6). The presence of LMW DNA (adjacent to 123-246-bp markers) in sPBA is shown in Fig. 8 (lanes 6-8) and discussed below.

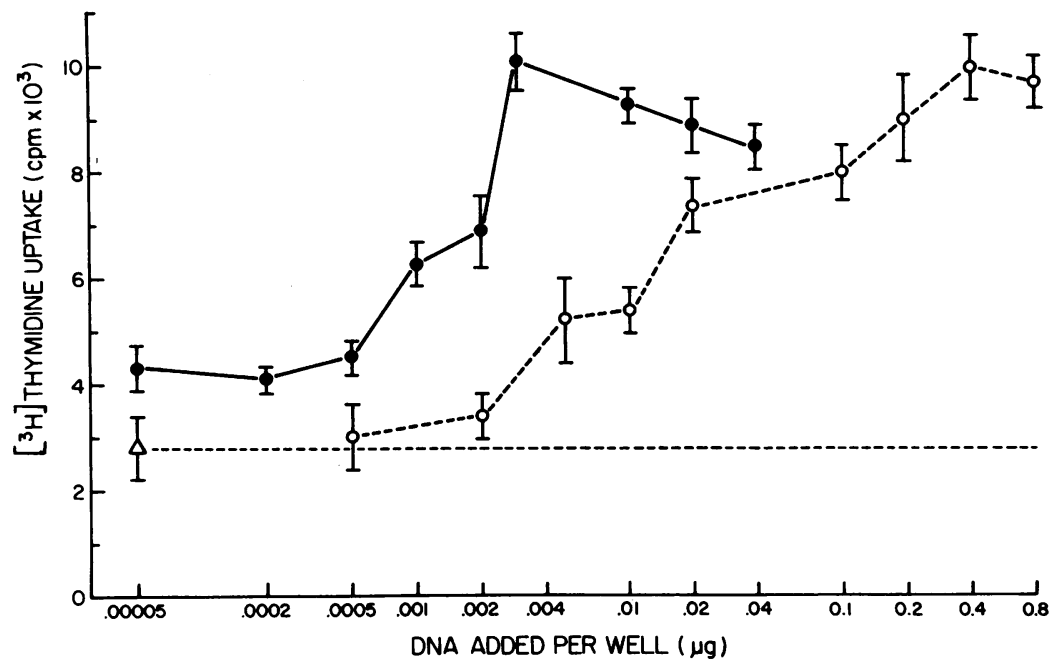

Figure 2. Comparative in vitro mitogenic effect of chicken erythrocyte nucleosomes and sPBA on normal mouse spleen cells. Graded concentrations in DNA equivalents of either sPBA from normal mouse cultures $(O)$ or purified chicken erythrocyte nucleosomes $(\bullet)$ were added to microcultures of normal DBA/ 2 spleen cells $\left(5 \times 10^{5} / \mathrm{ml}\right)$ in serum-free MEM and cultured in quadruplicate. The proliferative response was measured as in Fig. 1 by $\left[{ }^{3} \mathrm{H}\right]$ thymidine uptake at $48 \mathrm{~h}$. The data represent mean \pm SEM of quadruplicate cultures of a representative experiment. Significant differences in the proliferative response compared with unstimulated control cultures $(\Delta)$ were seen with as little as $0.002 \mu \mathrm{g}$ of DNA equivalents of chicken erythrocyte nucleosomes $(P$ $<0.005$ ) or with as little as $0.004 \mu \mathrm{g}$ of DNA equivalents of sPBA $(P<0.01)$. 


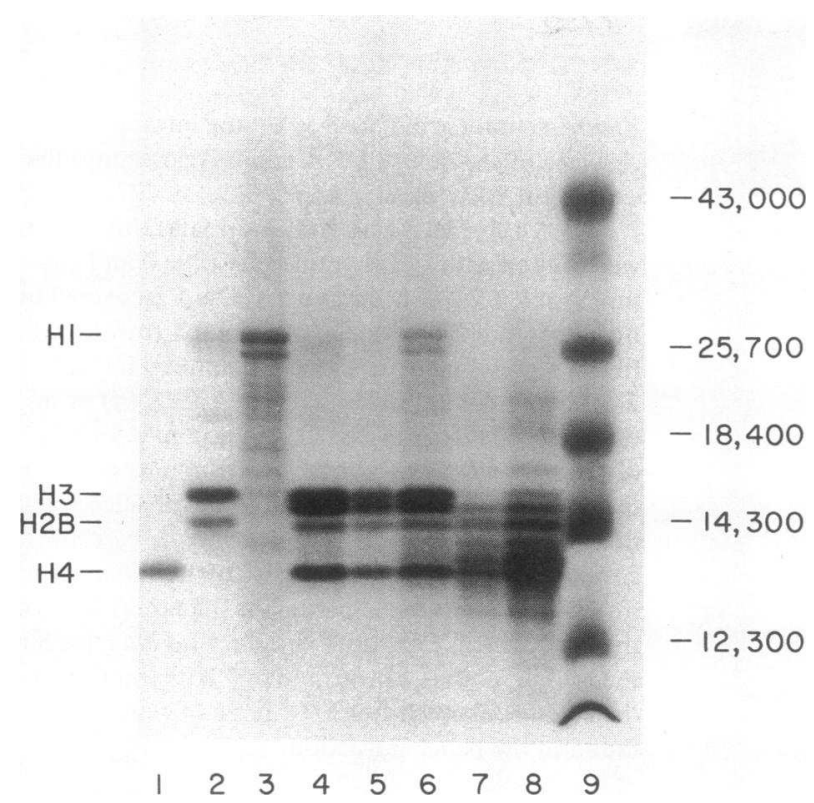

Figure 3. SDS-PAGE of sPBA, nucleohistone (SNH), calf thymus nucleosomes, and chicken erythrocyte nucleosomes. $20 \mu \mathrm{g}$ of each preparation was loaded onto the gels as described (see Methods). Lane 1, H4; lane 2, H3 + (H2B); lane 3, H1; lane 4, chicken erythrocyte nucleosomes; lane 5, calf thymus nucleosomes; lane 6, sPBA; lane 7, SNH at $20 \mu \mathrm{g}$; lane $8, \mathrm{SNH}$ at $40 \mu \mathrm{g}$; lane 9, BRL molecular weight marker.

Comparative effects of SPBA and calf thymus nucleosomes on Ig synthesis of murine splenic lymphocytes

In a previous report we showed that SPBA could directly stimulate B cells augmenting spontaneous in vitro antibody responses to a variety of unrelated protein antigens, as well as SRBC and DNA (9). Therefore, experiments were undertaken to determine whether a similar polyclonal B cell response could also be produced in vitro with SPBA and isolated nucleosomes. In these experiments the polyclonal B lymphocyte response of normal whole mouse spleen cells after the addition of calf thymus nucleosomes or SPBA was measured by the in vitro-enhancement of total protein A Ig PFC on day 4 of culture. These studies (Table I) showed that calf thymus nu-

Table I. Effect of SPBA and Calf Thymus Nucleosomes on In Vitro Ig Synthesis by Normal (DBA/2) Mouse Spleen Cells

\begin{tabular}{llll}
\hline & \multicolumn{3}{c}{ PFC/culture $\times 10^{3 *}$} \\
\cline { 2 - 4 } Concentration $^{*}$ & \multicolumn{1}{c}{ SPBA } & Nucleosomes \\
\hline 0 & \multicolumn{3}{c}{$15.3 \pm 3$} \\
0.01 & $25 \pm 2(P<0.005)^{\S}$ & $43 \pm 2(P<0.005)^{\S}$ \\
0.05 & $38 \pm 4(P<0.005)$ & $15 \pm 1$ & NS \\
1.00 & $20 \pm 1(P<0.05)$ & NT & \\
& & &
\end{tabular}

* Data represent total (mean \pm SEM) number of protein A PFC per culture $\times 10^{3}$ at day 4 of culture. Spleen cells were cultured in triplicate at $10^{7}$ cells $/ \mathrm{ml}$.

${ }^{\ddagger}$ Concentration represents DNA concentration (micrograms per well) of each preparation by diphenylamine assay.

${ }^{8} P$ values refer to response differences vs. controls containing medium only. cleosomes could mimic the SPBA-induced, polyclonal, in vitro enhancement of Ig synthesis. A comparison of peak responses to SPBA, calf thymus, and chicken erythrocyte nucleosomes consistently revealed that peak augmentation of Ig synthesis was observed at similar DNA equivalent concentrations of this material. Somewhat lower concentrations were required to achieve peak lymphoproliferative effects, measured by DNA synthesis.

\section{Influence of modulation of apoptosis on the release of $s P B A$ and its immunoproliferative effects in vitro}

The foregoing experiments indicated that the immunoproliferative effect of SPBA could be mimicked by purified DNA histone complexes from several sources including commercial nucleohistone preparations, isolated calf thymus, or chicken erythrocyte nucleosomes. Since mitogenically active fractions of $>30 \mathrm{kD}$ sPBA contained core histones and LMW DNA, it was reasoned that sPBA represented chromatin in the form of nucleosomes, and that these nucleosomes were responsible for its immunoproliferative effects. Since other investigators have shown that intact nucleosomes are released spontaneously from cells in vitro through a form of nonnecrotic cell death, termed apoptosis (11), we considered that this phenomenon might also explain the spontaneous cellular release of sPBA into the cell-free supernatant during culture. Apoptotic cell death has been shown to be dependent on and associated with the intracellular cleavage of chromatin internucleosomal linker DNA by nuclear endonucleases and can be blocked by $\mathrm{ZnSO}_{4}$ (23). Accordingly, in the following experiments we sought to determine in these cultured nonstimulated mouse spleen cells whether intracellular cleaved chromatin could be demonstrated intracellularly during early culture, whether the inhibition of this process of chromatin cleavage could be blocked with $\mathrm{ZnSO}_{4}$ and whether $\mathrm{ZnSO}_{4}$ could also inhibit both release of sPBA and block its immunoproliferative effects.

Evidence for spontaneous in vitro apoptosis in mouse lymphoid cells and its inhibition with $\mathrm{ZnSO}_{4}$. First, to determine whether intracellular cleavage of chromatin could occur spontaneously in murine lymphoid cells in vitro, nonstimulated spleen or thymic lymphocytes were pulsed with $\left[{ }^{3} \mathrm{H}\right]$ thymidine at time 0 of culture and the labeled DNA was chased in the cells harvested at $2,5,24,48$, and $72 \mathrm{~h}$ of culture, or in the cell-free $(>30 \mathrm{kD})$ supernatant fractions at each of these times. The cells were washed and their lysates centrifuged at $27,000 \mathrm{~g}$ as described previously (20), and the counts per minute of $\left[{ }^{3} \mathrm{H}\right]$ thymidine incorporated into DNA was determined from the TCA-precipitated, phenol chloroform-extracted DNA in the pellet (HMW noncleaved chromatin) or the supernatant (LMW cleaved chromatin) fractions (Fig. 4). In the absence of $\mathrm{ZnSO}_{4}$ (Fig. $4 \mathrm{~A}$ ), and using sedimentation criteria as an indication of chromatin cleavage, at 2 and 5 h HMW DNA constituted 80 and $50 \%$, respectively, of the labeled intracellular DNA, and this proportion of intracellular DNA in the HMW fraction progressively declined by $72 \mathrm{~h}$. In contrast, during the same time period an increasingly greater amount of the labeled intracellular DNA was found in the LMW fraction (at $24 \mathrm{~h}$ of culture $50 \%$ of the intracellular DNA was in the LMW fraction). In contrast to this, in the supernatant cell-free fractions, labeled DNA was identified as early as $5 \mathrm{~h}$ of culture, and progressively increased by $72 \mathrm{~h}$. Virtually all of the labeled DNA in the supernatant was in the LMW fraction. Similar results were noted with cultures of thymic $T$ cells (data not 


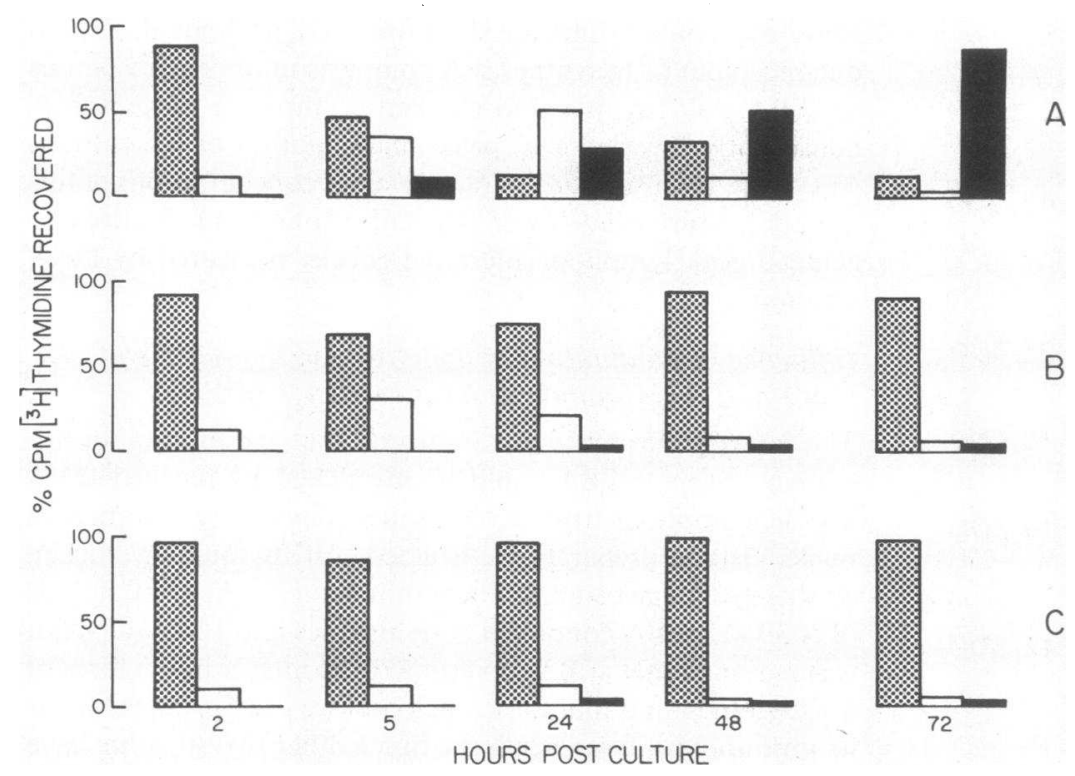

Figure 4. Influence of $\mathrm{ZnSO}_{4}$ on the intracellular cleavage of chromatin DNA and its release into the extracellular, cell-free $\mathrm{S} / \mathrm{N}$.

$1.5 \times 10^{6}$ spleen cells from normal (DBA/2) mice were pulsed with $\left[{ }^{3} \mathrm{H}\right]$ thymidine at time 0 and cultured for 2-72 $\mathrm{h}$. The amount of DNA recovered in the intracellular or extracellular compartment (cellfree $\mathrm{S} / \mathrm{N}$ ) was calculated for cells cultured for 2,5 , 24,48 , and $72 \mathrm{~h}$ in the absence of $\mathrm{ZnSO}_{4}(A)$ or in the presence of $1 \mathrm{mM} \mathrm{ZnSO}_{4}(B)$ or $5 \mathrm{mM} \mathrm{ZnSO}_{4}$ (C). Stippled bars, percent recovery counts per minute of $\left[{ }^{3} \mathrm{H}\right]$ thymidine recovered in the pelleted fraction of the cell lysate (HMW); open bars, percent recovery counts per minute of $\left[{ }^{3} \mathrm{H}\right]$ thymidine recovered from the nonpelleted supernatant fraction (LMW) of the cell lysate at each time period; solid bars, percent recovery of counts per minute of $\left[{ }^{3} \mathrm{H}\right]$ thymidine in the extracellular cell-free $S / N$, none of which was found in the pelleted fraction.

shown). These experiments indicate that intracellular cleavage of chromatin DNA in these cells was at least $50 \%$ complete by $24 \mathrm{~h}$ of culture, and with further cell death most if not all of the labeled DNA could be recovered in the LMW cell-free supernatant fraction. Most of the expected calculated quantity of intracellular DNA (24) expected in these cultured spleen cells $\left(4.6 \mathrm{pg} / \mathrm{cell}\right.$ in $\left.1.5 \times 10^{6} \mathrm{cells} / \mathrm{ml}\right)$ could be accounted for in the cell-free supernatant by $72 \mathrm{~h}$ of culture.

Since $\mathrm{ZnSO}_{4}$ has been shown to block chromatin cleavage during the apoptotic process, several different experiments were performed to evaluate in these cultured murine spleen cells the effects of $\mathrm{Zn}^{+}$both on the intracellular cleavage of chromatin and its release in the form of LMW DNA. Fig. 4, $B$ and $C$ demonstrate the effects of preculturing spleen cells with $\mathrm{ZnSO}_{4}$. In these experiments cells were first pulsed at time 0 with $\left[{ }^{3} \mathrm{H}\right]$ thymidine as before, and $2 \mathrm{~h}$ later the pulsed cells were washed and resuspended in MEM containing $10 \%$ FCS with $1 \mathrm{mM}$ (Fig. $4 \mathrm{~B}$ ) or $5 \mathrm{mM}$ (Fig. $4 \mathrm{C}$ ) $\mathrm{ZnSO}_{4}$. Fig. $4 \mathrm{~A}$ shows the effects on cells that were precultured with MEM containing $10 \%$ FCS without the addition of $\mathrm{ZnSO}_{4}$ as described above. The cells were lysed at $2,5,24,48$, and $72 \mathrm{~h}$ after exposure to $\left[{ }^{3} \mathrm{H}\right]$ thymidine, and the distribution of DNA (counts per minute of $\left[{ }^{3} \mathrm{H}\right]$ thymidine) into HMW (pelleted) fraction or LMW (nonpelleted supernatant) fraction was determined. In addition, a nuclear lysate of an aliquot of cells from each culture period was obtained and the extracted DNA was electrophoresed on agarose gels, stained with ethidium bromide, and examined for evidence of DNA cleavage. Fig. 4 shows that in those cells pre-exposed to $1 \mathrm{mM} \mathrm{ZnSO}_{4}$ (Fig. $4 \mathrm{~B}$ ) compared with cells not pre-exposed to $\mathrm{ZnSO}_{4},>70-80 \%$ of the labeled intracellular DNA remained in the HMW fraction (percent recovery of counts per minute $\left[{ }^{3} \mathrm{H}\right]$ thymidine in the pelleted fraction), suggesting that chromatin cleavage was inhibited. This resulted in the release of little if any labeled DNA into the cell-free supernatant by $72 \mathrm{~h}$ of culture. Similar more pronounced effects were noted when the cells were cultured in the presence of $5 \mathrm{mM} \mathrm{ZnSO}_{4}$ (Fig. $4 \mathrm{C}$ ). Parallel results were obtained in experiments in which DNA containing chromatin was obtained directly from nuclear rather than whole cell lysates (data not shown).
Fig. 5 shows the results of the ethidium bromide agarose gel electrophoresis of DNA obtained from the nuclear lysates of cells cultured in the presence or absence of $1 \mathrm{mM} \mathrm{ZnSO}_{4}$ over different time periods and DNA from the corresponding extracellular supernatant. These experiments that confirm the previous sedimentation studies (Fig. 4) show that virtually all of the intracellular DNA detected in 2-h pulsed cells is HMW DNA ( $>2 \mathrm{~kb}$ as shown in lane 2), while the DNA obtained from nuclear lysates of cells pulsed for 4-72 h (lanes 3-5) revealed increasingly greater amounts of DNA of lower molecular weight. The DNA from the supernatant of cells cultured for 24-72 h (lanes 6-8) was predominately of relatively low molecular weight and between 123 and 246 bp in size. In contrast to this, virtually all of the detectable DNA from nuclear lysates of cells cultured in the presence of $1 \mathrm{mM} \mathrm{ZnSO}_{4}$ (lanes 10-12) appeared to be $>2 \mathrm{~kb}$, and none could be detected in the 24-72-h supernatants (lanes 13-15). Taken together, these data imply that while nuclear chromatin DNA from cells cultured 24-72 h underwent spontaneous cleavage in vitro, in the presence of $1 \mathrm{mM} \mathrm{ZnSO}_{4}$ most if not all of the nuclear DNA remained in a high molecular weight noncleaved format and was not released into the supernatant. This was demonstrated by both the sedimentation properties of $\left[{ }^{3} \mathrm{H}\right]$ thymidine-labeled DNA at different times of culture shown in the pulse-chase experiments and by the molecular size of the DNA from the nuclear lysates from cultured cells revealed in agarose gels stained with ethidium bromide. These zinc-pretreated cells also failed to release the histone constituents of core nucleosomes (data not shown).

Functional studies. Since $\mathrm{ZnSO}_{4}$ appeared to block the spontaneous intracellular cleavage of chromatin DNA and its release into the cell-free supernatant, experiments were undertaken to evaluate whether inhibition of the apoptotic cleavage of chromatin DNA with $\mathrm{ZnSO}_{4}$ also had a parallel inhibitory effect on the immunoproliferative response to released sPBA in the supernatant. In the first of these experiments spleen cells were cultured for $96 \mathrm{~h}$ in medium with or without $1 \mathrm{mM}$ $\mathrm{ZnSO}_{4}$. The cell-free supernatants from these cultures were dialyzed extensively against $0.9 \%$ saline to remove $\mathrm{Zn}^{2+}$, and were then added at an optimal predetermined mitogenic con- 


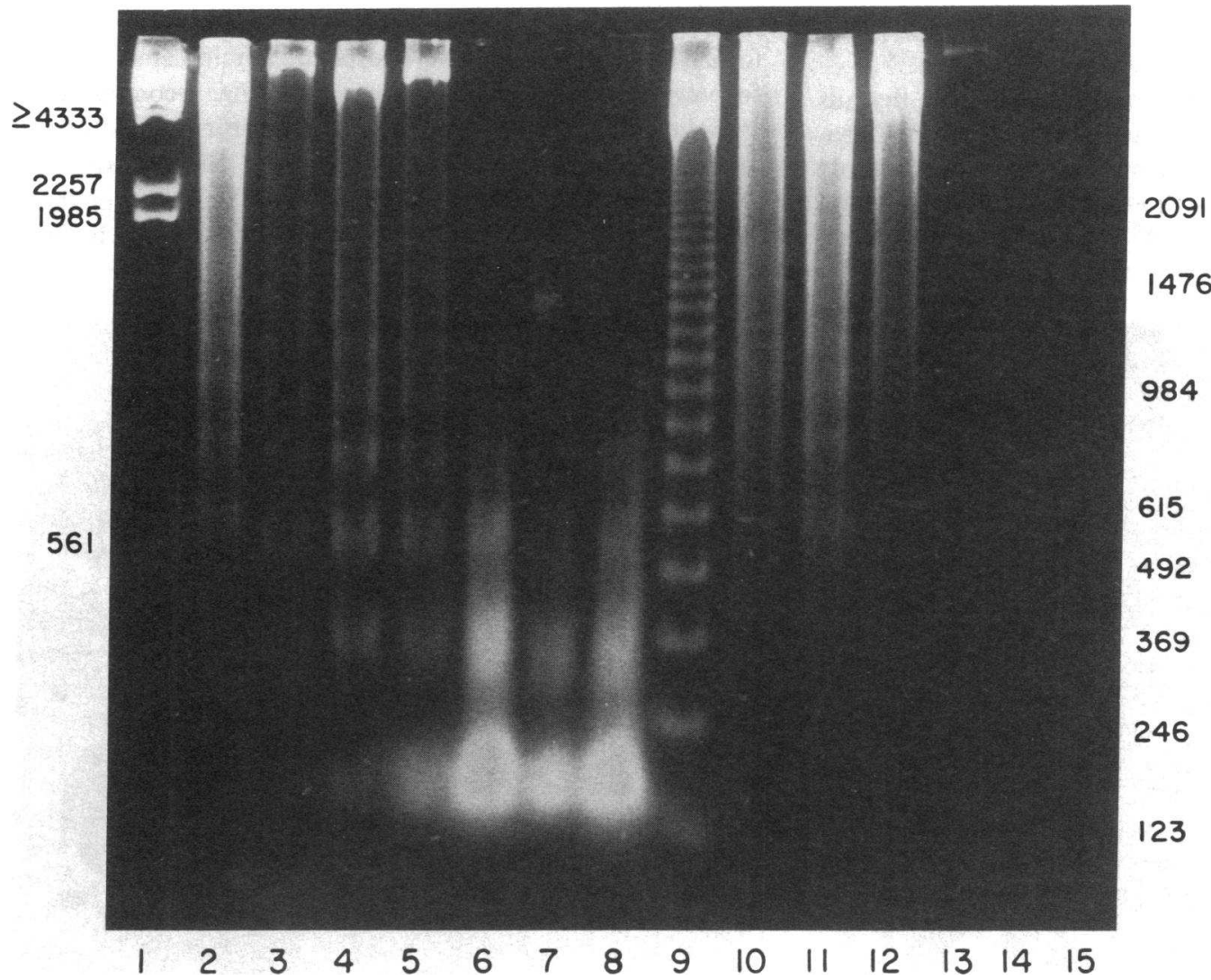

Figure 5. Size and relative quantity of intracellular and extracellular supernatant chromatin DNA from mouse spleen cells cultured in the presence or absence of $\mathrm{ZnSO}_{4}$, revealed by ethidium bromide agarose gel electrophoresis.

Aliquots of cell lysates (intracellular compartment) or cell-free supernatants (extracellular compartment) from Fig. 4 were prepared as described in Methods. Extracted DNA from $1.5 \times 10^{6}$ cells was applied to a $2.0 \%$ agarose gel and stained with ethidium bromide. The left vertical axis scale represents numbers of base pairs of DNA, and the right vertical axis, represents molecular weight markers.

Lane 1, DNA molecular weight marker PBR 321; lanes 2-5, intracellular DNA obtained from cells cultured in zinc-free medium for $2,24,48$, and 72 h, respectively; lanes $6-8$, extracellular supernatant

DNA of cells cultured for 24,48 , and $72 \mathrm{~h}$, respectively; lane 9, BRL marker; lanes 10-12, intracellular DNA from cells cultured in the presence of $1 \mathrm{mM} \mathrm{ZnSO}_{4}$ for 24,48 , and $72 \mathrm{~h}$; lanes $13-15$, cell-free supernatant of cells cultured in the presence of $1 \mathrm{mM} \mathrm{ZnSO}_{4}$ for 24,48 , and $72 \mathrm{~h}$, respectively.

centration $(<1: 10$, vol sPBA/vol of culture medium) to fresh spleen cells in culture medium at the initiation of culture. Control cultures contained an equivalent volume of the sterile filtered $0.9 \%$ saline of the final dialysate added. While such supernatants obtained from cells precultured without $\mathrm{ZnSO}_{4}$ showed the expected degree of enhancement of Ig synthesis (protein A PFC), enhancement of Ig synthesis was not observed with supernatants of cells precultured with $\mathrm{ZnSO}_{4}$ at $0.25 \mathrm{mM}$ or greater concentrations (Fig. 6). Supernatant from cells precultured with concentrations of $\mathrm{ZnSO}_{4}$ equal to or less than the reported extracellular $\mathrm{Zn}^{2+}$ concentration (25) reported in normal tissue fluid $(0.1 \mathrm{mM}$ or less) had no blocking effect and supported enhancement of Ig synthesis. This effect of pretreatment of cells with $\mathrm{ZnSO}_{4}$ was not due to the direct effect of $\mathrm{ZnSO}_{4}$ or other potentially suppressive molecules $>30 \mathrm{kD}$ carried over to the fresh cultured cells since the immunoproliferative effect on these cells by dialyzed sPBA-free supernatants could be restored with the addition of fresh sPBA.

The foregoing experiments taken together thus indicate that $\mathrm{ZnSO}_{4}$, at concentrations greater than normally expected in the extracellular fluid $(>0.1 \mathrm{mM})$, are capable of blocking cleavage of chromatin DNA and the release from cells of LMW chromatin DNA and core histones. This inhibition of release of LMW chromatin DNA and histones was accompanied by a parallel loss in the immunoproliferative effects of this supernatant factor (sPBA).

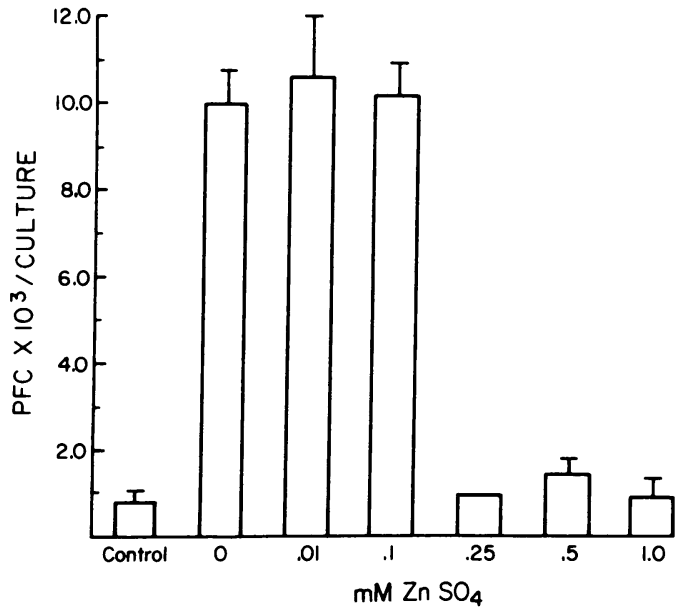

Figure 6. The influence of $\mathrm{ZnSO}_{4}$ on the release of sPBA activity from normal mouse spleen cells. Normal (DBA/2) spleen lymphocytes were cultured at $10 \times 10^{6}$ cells in medium, with or without $\mathrm{ZnSO}_{4}$ at various concentrations $(0.01,0.1,0.25,0.5$, and $1 \mathrm{mM}$ $\mathrm{ZnSO}_{4}$ ) for $96 \mathrm{~h}$ ( $x$ axis). Filtered $>30 \mathrm{kD}$ cell-free supernatants of these cell cultures were then extensively dialyzed to remove $\mathrm{ZnSO}_{4}$ and added at previously determined optimal concentrations to fresh normal spleen cells at culture initiation. The response of spleen cells to these supernatants was measured by the number of IgG PFC (Protein A PFC) on day 5 of culture. The $y$ axis represents the number of protein A PFC \pm SEM per culture of replicate cultures plated in triplicate. 
Morphologic analysis of cultured mouse spleen or thymic lymphoid cells for evidence of apoptosis (Fig. 7).

Mononuclear cells form normal mouse spleen and thymus were cultured to determine whether changes typical of apoptotic cell death could be detected. The cells were cultured under the same conditions as those used to label cells with $\left[{ }^{3} \mathrm{H}\right]$ thymidine to detect cleavage of intracellular and extracel- lular chromatin. Noncultured cells were suspended in medium for $2 \mathrm{~h}$ and cultured cells were suspended in the same medium for varying periods of time, up to $72 \mathrm{~h}$. Fig. 7 compares the morphologic appearance of nuclear chromatin in noncultured and cultured cells from these two sources. Noncultured cells revealed a pattern of nuclear chromatin dispersed throughout the nucleus, while cells cultured for 24-72 h showed features
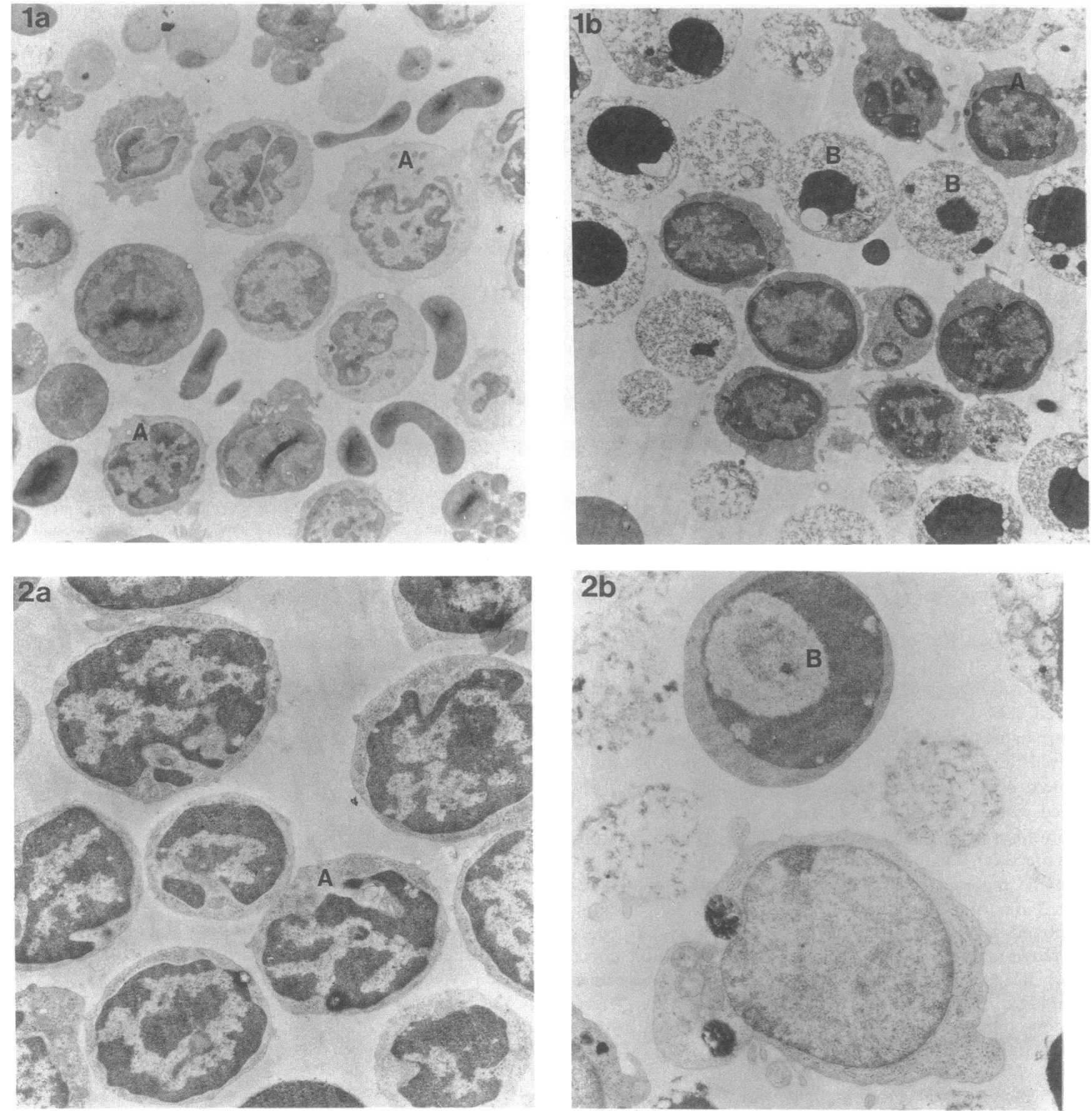

Figure 7. Morphology of cultured and noncultured murine spleen and thymic lymphocytes. Mononuclear cells from normal mouse (DBA/2) spleen and thymus were prepared as described for cell cultures. Noncultured cells were left in medium for $2 \mathrm{~h}$ and cultured cells were suspended in the same medium for 24,48 , or $72 \mathrm{~h}$. The cells were fixed and prepared for electron microscopy as described in Methods. Staining was performed with $1 \%$ aqueous uranyl acetate and Reynolds lead citrate. Normal mouse spleen cells $(1 a)$ at $2 \mathrm{~h}(\times 4,900)$ reveal cells with normal nuclear chromatin $(A)$, or spleen cells cultured for $48 \mathrm{~h}(\times 4,900)(I b)$ reveal cells undergoing apoptotic cell death with condensation of nuclear chromatin $(B)$ or normal chromatin $(A)$. Noncultured normal mouse thymus cells $(2 a)$ show normal nuclear chromatin morphology $(A)$, and mouse thymus cells cultured $72 \mathrm{~h}(2 b)$ show eccentric localization of condensed nuclear chromatin $(B)$ typical of apoptosis $(\times 12,600)$. 
reported previously among cells undergoing apoptotic cell death, including condensation of nuclear chromatin and its concentration or polarization against the nuclear membrane in some instances (mouse thymus), revealing a typical crescentic pattern. These changes are typical of those described by others for cells undergoing apoptotic programmed cell death (26).

\section{Discussion}

Normal and preautoimmune murine splenic lymphoid cells cultured in vitro in the absence of added antigen spontaneously produce anti-DNA and antihistone antibodies $(1,27)$. The present experiments provide evidence that important stimuli for the in vitro anti-DNA response, previously attributed to a $>30 \mathrm{kD}$ DNA-protein factor (sPBA) spontaneously released by these cultured murine lymphoid cells (9), are the nucleosome constituents of chromatin. These LMW DNAhistone complexes can be identified early in cell-free supernatants of these cultured cells. Moreover, the immunoproliferative effects of sPBA can be mimicked by isolated, purified nucleosomes from several different sources, including chicken erythrocytes and calf thymus. PAGE revealed that SPBA contains core histone constituents of nucleosomes similar to those present in these additional purified nucleosomal preparations. SPBA also contains LMW DNA revealed by ethidium bromide agarose gel electrophoresis. We also present evidence that these nucleosomes are released by cultured spleen cells through a process similar to the active form of programmed cell death, termed apoptosis (11). This process has been described both in vitro and in vivo in both rodent and human lymphoid and nonlymphoid tissues. Morphologic evidence for this process is shown here with changes in nuclear chromatin in thymic and splenic lymphoid cells consistent with changes described by others in cells undergoing apoptotic cell death (26). The spontaneous cellular release of intact mono- and dinucleosomes shown to result from this process has been shown to be dependent on the presence of $\mathrm{Ca}^{2+} \mathrm{Mg}^{2+}$-dependent endonuclease cleavage of internucleosomal linker DNA in chromatin (23). Zinc has been reported to block the effects of endonuclease and hence block the cleavage and extracellular release of cleaved chromatin in the form of mono- and dinucleosomes (23). Here we have observed that the rapid intracellular cleavage of $\left[{ }^{3} \mathrm{H}\right]$ thymidine-labeled DNA in cultured spleen or thymic lymphoid cells could be blocked when these lymphoid cells were precultured with $\mathrm{ZnSO}_{4}$ at concentrations higher than reported in the extracellular space (27) but similar to the concentrations reported by others $\left(\sim 5 \mathrm{mM} \mathrm{ZnSO}_{4}\right)$ to block apoptosis (23). Such pretreatment blocks both the recovery of labeled LMW DNA and core histones from the cell-free supernatants and the immunoproliferative effects of these supernatants. This loss of the immunoproliferative properties of the dialyzed $\mathrm{Zn}^{2+}$-free, cell-free supernatant could be restored by the addition of fresh SPBA. These studies therefore provide morphologic and biochemical evidence for the occurrence of spontaneous apoptosis as the basis for cell death in this culture system, and indicate that the intracellular cleavage and release of chromatin is necessary for both the recovery of nucleosomal constituents of SPBA in the supernatant and their immunoproliferative effects.

The present experiments also relate to some earlier observations from our laboratory on the specific immunogenic effects of LMW DNA released in vitro primarily from murine splenic $\mathrm{T}$ cells and thymocytes, and its effect on the in vitro
anti-DNA antibody responses of normal and preautoimmune $\mathrm{NZB} / \mathrm{W}$ mice $(7,8)$. In these experiments extracted proteinfree purified LMW DNA recovered from cell-free cultures could generate an anti-DNA PFC response, but had neither a mitogenic nor a polyclonal effect. The polyclonal and mitogenic effects of SPBA, and the nucleohistone preparations shown here, appear to be dependent on the presence of a protein (histone) moiety, since naked DNA extracted from these preparations had no immunoproliferative or mitogenic effects. The basis for the different in vitro responses to naked LMW DNA on the one hand, versus DNA complexed to histone proteins in the context of nucleosomes on the other, is not established here. It is conceivable, however, that the mitogenic and polyclonal effects on B cells may be dependent on some conformation of DNA imposed by histones, or alternatively that this broader effect is dependent on the presence of histones themselves and their binding to cell membrane receptors. We have, however, tested core chicken erythrocyte histones for their immunoproliferative effects, and none have been observed. Moreover, previous studies indicated that the effects of sPBA could not be abrogated with proteases alone (9). Further, the immunoproliferative effect could be absorbed out with monoclonal anti-DNA antibodies (9). Thus, it is likely that this effect of nucleosomes is dependent on the presence of the LMW DNA present in nucleosomes, and is not solely dependent on the presence of histones present in intact nucleosomes. These observations leave the possibility that nucleosomes bind to their target lymphoid cells through specific receptors for DNA. In this regard, however, it is of interest that Bennett et al. (28) have reported on the presence of a specific DNA receptor on the surface of a variety of nucleated lymphoid and nonlymphoid cells, and have isolated an antibody that blocks the binding of DNA to this receptor (29). The immunobiological consequences of this binding have not yet been reported.

While the in vivo relevance of these observations is not established in this report, there are several obvious potential implications to consider in this respect. First, since apoptotic cell death appears to be a ubiquitous normal process, it could result in the local in vivo release of nucleosomes in tissues and influence cell turnover. For example, morphologic evidence for apoptosis has been noted in human lymphoid tumors (30), and there is abundant evidence that this process occurs in thymic cortical cells of mice treated with corticosteroids. Cell death resulting from cytolytic $\mathrm{T}$ cells has also been attributed to apoptosis (31). Release of nucleosomes from these dying cells under such circumstances could lead to the renewed proliferation of cells in the adjacent milieu, and hence the whole process itself may be important in normal or abnormal lymphoid cell homeostasis.

Second, several of the spontaneous autoantibody responses and other immune phenomena seen in idiopathic and procainamide SLE anticipate the possible immunoproliferative influence of nucleosomes in these disorders. These include polyclonal B cell activation and proliferation and the appearance of antibodies to DNA and nucleosomes, including the LE cell factor. The spontaneous antihistone antibody response observed in idiopathic and drug-induced SLE, with preference for the trypsin-sensitive $\mathrm{NH}_{2}$-terminal regions of the most exposed histones in the context of nucleosomes $(18,32)$, is also a compelling argument for the potential immunoproliferative effect of nucleosome immunogenic factors in this disorder. A recent report has also indicated the existence of nucleosomes 
in the plasma of normals and SLE patients (33) with much higher concentrations in SLE. These observations are consistent with the possibility that in vivo, DNA in the context of nucleosomes released from dying cells by apoptosis may be protected from exonuclease digestion as shown here, persist in the circulation or other tissue sites, and provide an important immunogenic or mitogenic stimulus for B cells.

The foregoing considerations indicate that further studies are warranted to evaluate the normal and abnormal regulation of apoptotic cell death and the specific way in which nucleosomes may influence cell proliferation in normals as well as in disease states where polyclonal lymphocyte activation is present.

\section{Acknowledgments}

We wish to thank Dr. Stephen Karlic, Department of Radiology, University of Western Ontario, for the provision of purified calf thymus nucleosomes, and Dr. Peter Lewis, Department of Biochemistry, University of Toronto, for the provision of chicken erythrocyte nucleosome preparations. We thank Mrs. Marlyn French for typing the manuscript and Dr. Ewa Cairns and Dr. Marvin Fritzler for reviewing the manuscript. The authors are grateful to Ms. Dianne Moyles, Department of Microbiology \& Immunology, University of Western Ontario, for performing the electron micrographs of cultured lymphoid cells.

This work was supported by a grant from the Medical Research Council of Canada.

\section{References}

1. Roder, J. C., D. A. Bell, and S. K. Singhal. 1978. Loss of self tolerance to single-stranded deoxyribonucleic acid (sDNA) in vitro. $J$. Immunol. 121:29-37.

2. Datta, S. K., B. D. Stollar, and R. S. Schwartz. 1980. Normal mice express idiotypes related to autoantibody idiotypes of lupus mice. Proc. Natl. Acad. Sci. (USA). 80:2723-2727.

3. Cairns, E., J. Block, and D. A. Bell. 1984. Anti-DNA autoantibody producing hybridomas of normal human lymphoid or cell origin. J. Clin. Invest. 74:880-887.

4. Bell, D. A., E. Cairns, K. Cikalo, V. Ly, J. Block, and W. Pruzanski. 1987. Antinucleic acid autoantibody responses of normal human origin: antigen specificity and idiotypic characteristics compared to SLE and patients with monoclonal IgM. J. Rheumatol. 14:127-131.

5. Mayus, J. L., and D. S. Pisetsky. 1985. Expression of a highly conserved anti-DNA idiotype in normal and autoimmune mice. Clin. Immunol. Immunopathol. 34:366-378.

6. Cairns, E., P. C. Kwong, V. Misener, P. Ip, D. A. Bell, and K. A. Siminovitch. 1989. Analysis of variable region genes encoding a human anti-DNA antibody of normal origin: implications for the molecular basis of human autoimmune responses. J. Immunol. 143:685-691.

7. Pancer, L. B., D. A. Bell, and S. K. Singhal. 1980. Induction of anti-ssDNA antibodies in normal and preautoimmune mice in vivo. $J$. Immunol. 124:939-946.

8. Pancer, L. B., M. F. Milazzo, V. Morris, S. K. Singhal, and D. A. Bell. 1981. Immunogenicity and characterization of supernatant DNA released by murine spleen cells. J. Immunol. 127:98-104.

9. Atkinson, M. J., D. A. Bell, and S. K. Singhal. 1985. A naturally occurring polyclonal B cell activator of normal and autoantibody responses. J. Immunol. 135:2524-2533.

10. Sperling, R., and E. J. Wachtel. 1981. The histone. Adv. Protein Chem. 34:1-60.

11. Kerr, J. F. R., A. H. Wyllie, and A. R. Currie. 1972. Apoptosis: a basic biological phenomenon with wide-ranging implications in tissue kinetics. Br. J. Cancer. 26:239-257.

12. Searle, J., J. F. R. Kerr, and C. J. Bishop. 1982. Necrosis and apoptosis: distinct modes of cell death with fundamentally differen significance. Pathol. Annu. 17:229-259.
13. Gronkowicz, E., A. Coutinho, and F. A. Melchers. 1976. A plaque assay for all cells secreting Ig of a given type or class. Eur. $J$. Immunol. 6:588-590.

14. Eickbush, T. H., and E. N. Moudrianakis. 1978. The histone core complex: an octamer assembled by two sets of protein-protein interactions. Biochemistry 17:4955-4964.

15. Chung, D. G., and P. N. Lewis. 1986. Intermolecular histone H4 interactions in core nucleosomes. Biochemistry. 25:2048-2054.

16. Giles, K. W., and A. Myers. 1965. An improved diphenylamine method for the estimation of deoxyribonucleic acid. Nature (Lond.). 209:93.

17. Thomas, J. O., and R. D. Kornberg. 1975. An octamer of histones in chromatin and free in solution. Proc. Natl. Acad. Sci. USA. 72:2626-2630.

18. Gohill, J., P. D. Cary, M. Couppez, and M. J. Fritzler. 1985. Antibodies from patients with drug-induced and idiopathic lupus erythematosus react with epitopes restricted to the amino and carboxyl termini of histone. J. Immunol. 135:3116-3121.

19. Thomas, J. O., C. M. Wilson, and J. A. Hardin. 1984. The major core histone antigenic determinants in SLE are in the trypsinsensitive regions. FEBS (Fed. Eur. Biochem. Soc.) Lett. 169:90-96.

20. Miovic, M. L., and L. I. Pizer. 1980. Characterization of RNA synthesized in isolated nuclei of herpes simplex virus type I-infected KB cells. J. Virol. 33:567-571.

21. Duke, R. C., R. Chervenak, and J. J. Cohen. 1983. Endogenous endonuclease-induced DNA fragmentation: an early event in cell-mediated cytolysis. Proc. Natl. Acad. Sci. USA. 80:6361-6365.

22. Maniatis, T., E. F. Fritsch, and J. Sambrook. 1982. Molecular Cloning: A Laboratory Manual. Cold Spring Harbor Laboratory, Cold Spring Harbor, NY. 468.

23. Cohen, J. J., and R. C. Duke. 1984. Glucocorticoid activation of a calcium-dependent endonuclease in thymocyte nuclei leads to cell death. J. Immunol. 132:38-42.

24. McCarthy, B. J. 1969. The evolution of base sequences in nucleic acids. In Handbook of Molecular Cytology. A. Lima-de Faria, editor. North-Holland Publishing Co., Amsterdam, The Netherlands. 3-20.

25. Purcell, S. K., K. M. Hambridge, and M. A. Jacobs. 1986. Zinc concentrations in mononuclear and polymorphonuclear leukocytes. Clin. Chim. Acta. 155:179-183.

26. Wyllie, A. H., R. G. Morris, A. L. Smith, and D. Dunlop. 1984. Chromatin cleavage in apoptosis: association with condensed chromatin morphology and dependence on macromolecular synthesis. $J$. Pathol. 142:67-77.

27. Portanova, J. P., B. L. Kotzin, E. A. Coleman, and H. N. Claman. 1984. Distribution of anti-histone-secreting cells in NZB/ NZW mice. Cell. Immunol. 87:485-493.

28. Bennett, R. M., G. T. Gabor, and M. M. Merritt. 1985. DNA binding to human leukocytes. Evidence for a receptor-mediated association, internalization and degradation of DNA. J. Clin. Invest. $76: 2182-2190$

29. Bennett, R. M., B. L. Kotzin, and M. J. Merritt. 1987. DNA receptor dysfunction in systemic lupus erythematosus and kindred disorders. Induction by anti-DNA antibodies, antihistone antibodies and antireceptor antibodies. J. Exp. Med. 166:850-863.

30. Kerr, J. F. R., and J. Searle. 1972. The digestion of cellular fragments within phagolysosomes in carcinoma cells. J. Pathol. 108:55-58.

31. Russell, J. H., V. Masakowski, T. Rucinsky, and G. Phillips. 1982. Mechanisms of immune lysis. III. Characterization of the nature and kinetics of the cytotoxic T-lymphocyte-induced nuclear lesion in the target. J. Immunol. 128:2087-2094.

32. Hardin, J. A., and J. O. Thomas. 1983. Antibodies to histones in systemic lupus erythematosus: localization of prominent autoantigens on histones HI and H2B. Proc. Natl. Acad. Sci. USA. 80:74107414.

33. Rumore, P., and C. Steinman. 1988. Nucleosome-like characteristics of circulating DNA in SLE. Arthritis Rheum. 31:D32. (Abstr.) 